Supporting Information

\title{
Inactivation of HIV-1 Infection through Integrative Blocking with Amino Phenylboronic Acid Attributed Carbon Dots
}

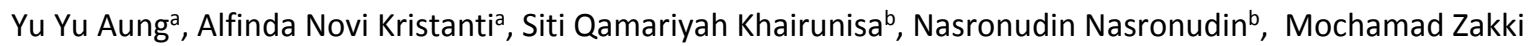
Fahmi, ${ }^{a, c^{*}}$

a. Department of Chemistry, Airlangga University, Surabaya 61115, Indonesia.

b. Institute of Tropical Disease, Airlangga University, Surabaya 61115, Indonesia.

c. Supra modification Nano-Micro Engineering Research Group, Airlangga University, Surabaya 61115, Indonesia.

(a)

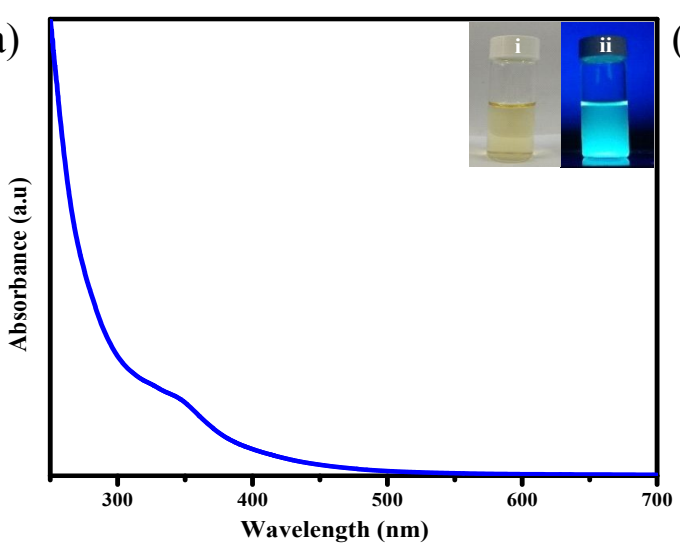

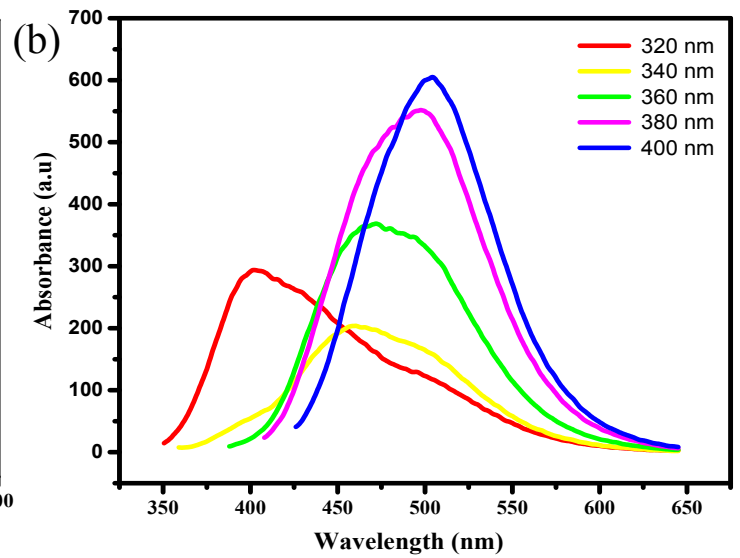

Figure S1. a) UV-Vis Spectra of APBA CDs. Insert: photographs of solution APBA-CDs under daylight (i) and UV lamp(ii). (b) Photoluminescence spectra of APBA-CDs at varied excitation wavelength (320-400nm). 
A
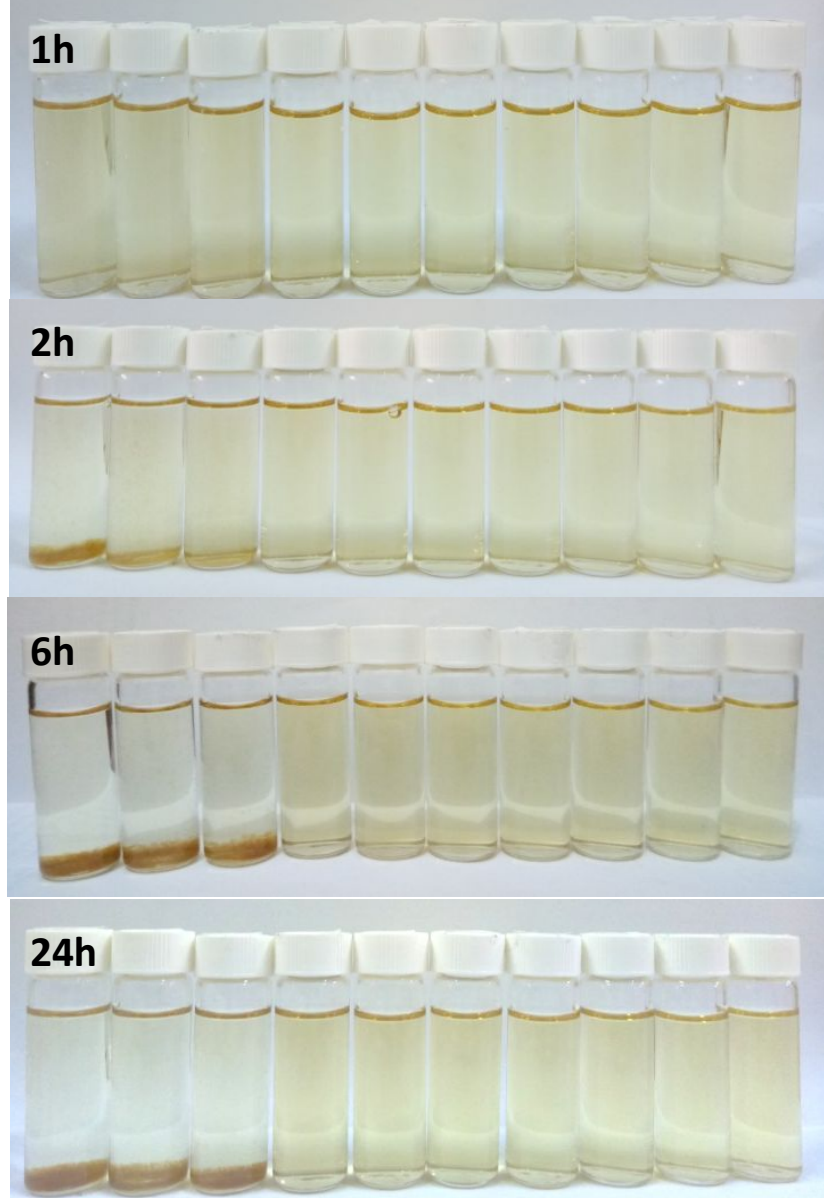

pH 3
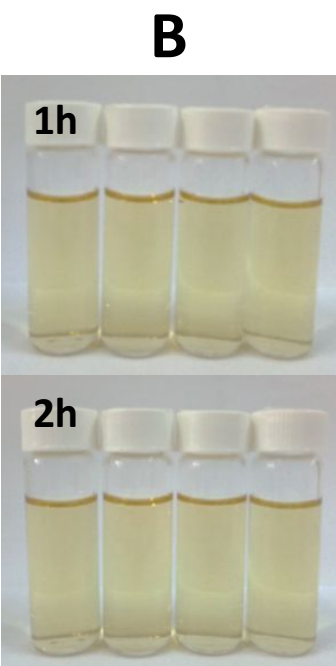

$6 \mathrm{~h}$

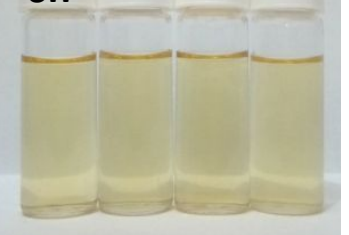

24h

$\begin{array}{lllllllll}12 & 0 & 0.15 & 0.3 & 0.5 \mathrm{M}\end{array}$

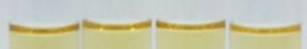

C

$30^{\circ} \mathrm{C}$

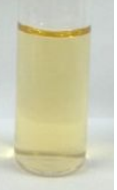

$50^{\circ} \mathrm{C}$

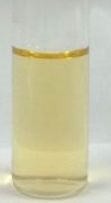

$70^{\circ} \mathrm{C}$
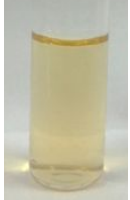

$100^{\circ} \mathrm{C}$

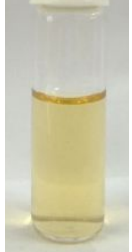
Figure S2. The Photograph images of APBA-CDs at $\mathrm{pH}$ variation (from 3 to 12 ) and time (a);
varied $\mathrm{NaCl}$ concentration (from 0 to $0.5 \mathrm{M}$ ) and time (b); and temperature (from 30 to $100^{\circ} \mathrm{C}$ ) (c).
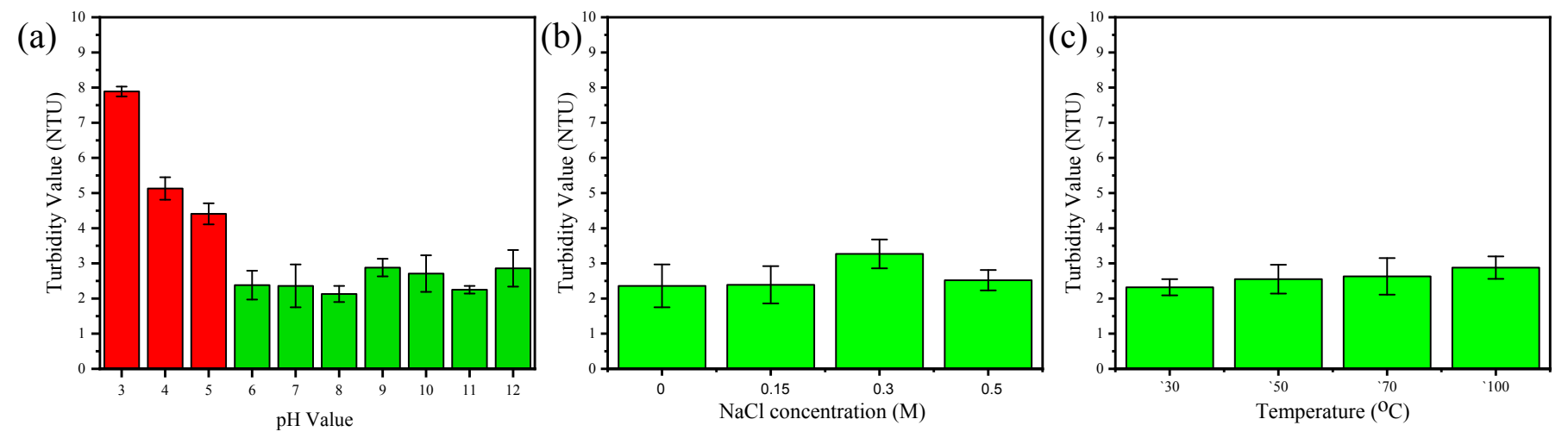

Figure S3. Graph of turbidity values of APBA-CDs after $24 \mathrm{~h}$ on varied (a) $\mathrm{pH}$, (b) $\mathrm{NaCl}$ concentration, and (c) temperature. 


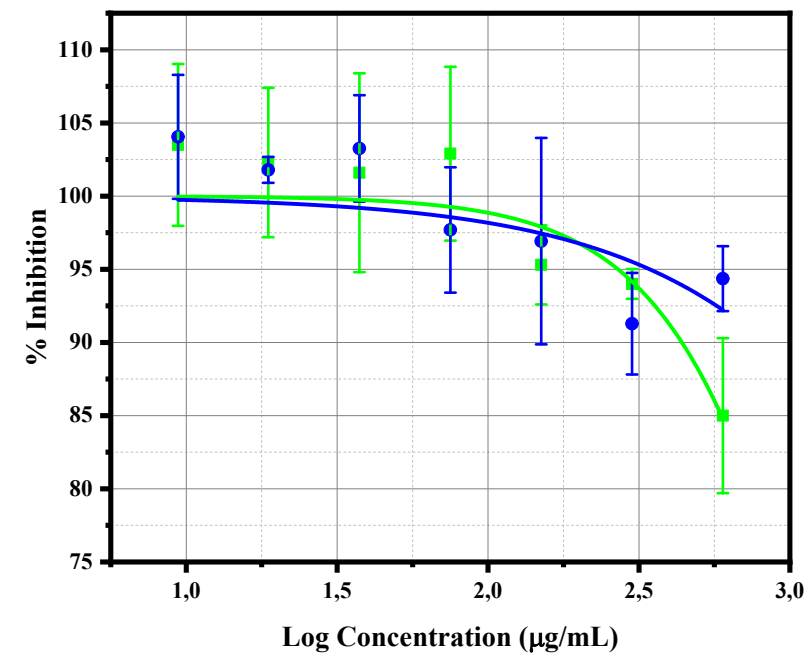

Figure S4. a) Comparison cell viability of MOLT-4 cancer cells after $24 \mathrm{~h}$ incubation with CACDs (green line) and APBA-CDs (blue line). $\mathrm{CC}_{50}$ values from fitted curve are resulted from doses response mode on Origin software, which show at 4.26 and $5.55 \mathrm{mg} / \mathrm{mL}$ for each $\log$ [Sample] or at 19.9 and $354.8 \mathrm{mg} / \mathrm{mL}$ for each [Sample], respectively.

(a)
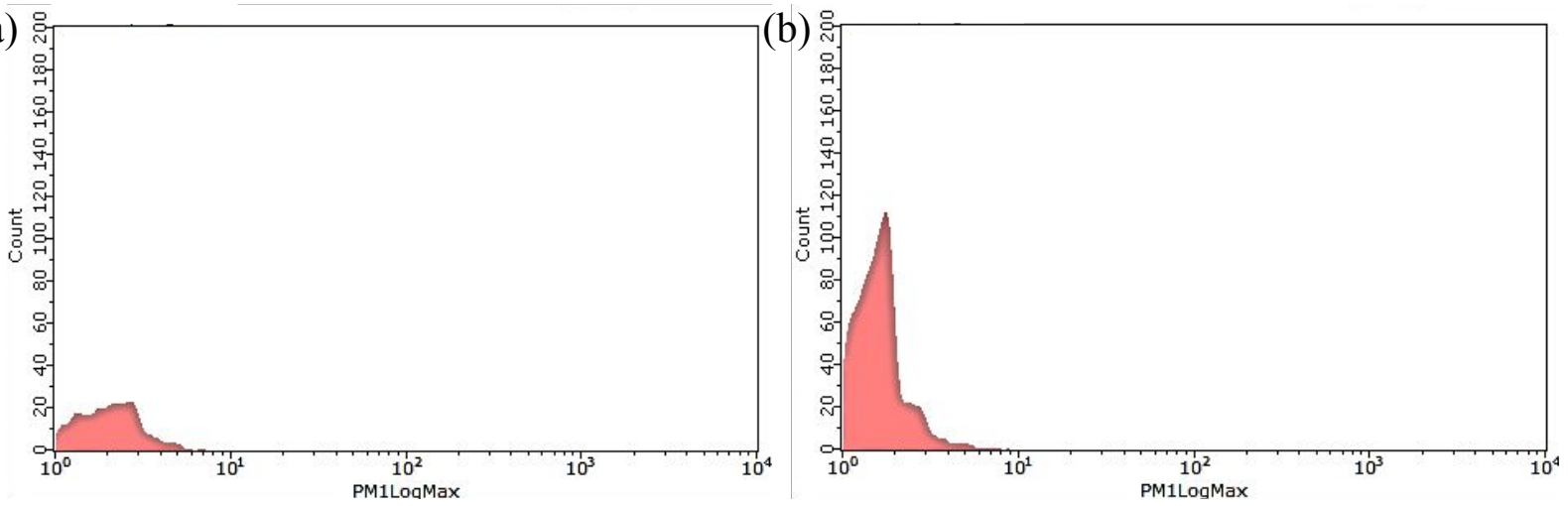

Figure S5. Comparison fluorescent intensity of APBA-CDs on (a) MOLT-4 cancer cells and (b) HIV-1 infected MT-4 after $24 \mathrm{~h}$ incubation 

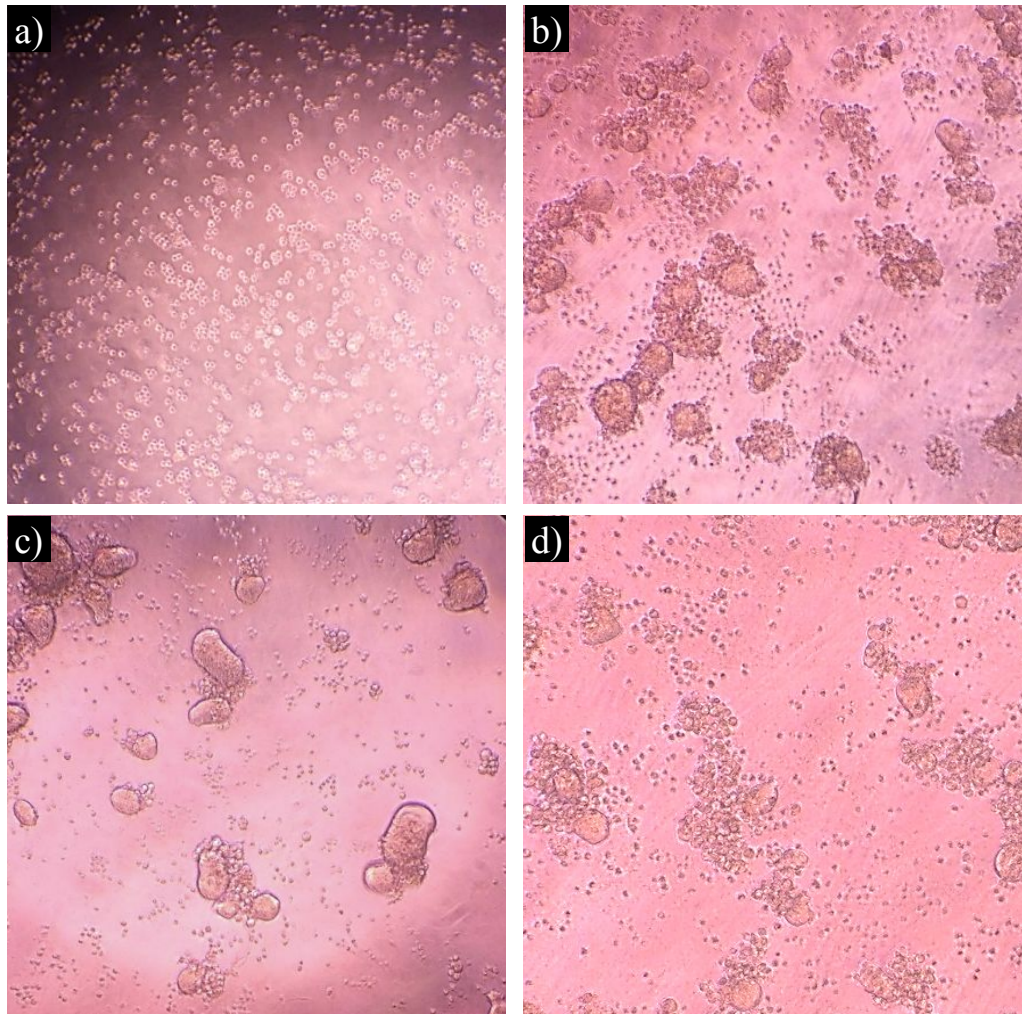

Figure S6. Microscopical images of a) MOLT-4 cell and b) MT-4/HIV-1 cell as control. c) microscopical images of MOLT-4 cell after post $24 \mathrm{~h}$ infected with MT-4/HIV-1 with addition of CACDs (c) and APBA-CDs (d). The syncitia is showed as non-spherical bubbles on figure $b$ to d.

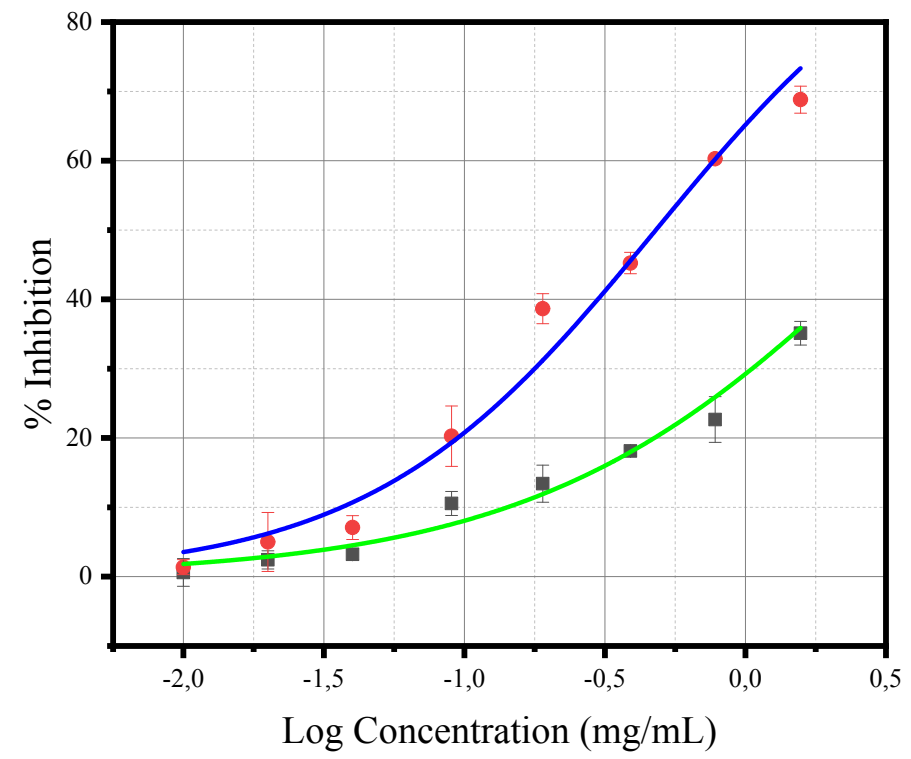

Figure S7. Inhibition curve MT-4/HIV-1 on MOLT-4 after $24 \mathrm{~h}$ with presence of CACDs (green line) and $\mathrm{APBA}-\mathrm{CDs}$ (blue line). $\mathrm{EC}_{50}$ values is determined the curve fitting using doses 
response mode on Origin software, which show at $0,57 \mathrm{mg} / \mathrm{mL}$ and $-0.32 \mathrm{mg} / \mathrm{mL}$ for each $\log$ [Sample] or at $3.72 \mathrm{mg} / \mathrm{mL}$ and $0.48 \mathrm{mg} / \mathrm{mL}$ for each [Sample], respectively.

Table S1. Comparison $\mathrm{EC}_{50}$ and $\mathrm{CC}_{50}$ values from previous studies and current report.

\begin{tabular}{|c|c|c|c|c|c|c|}
\hline No & Compound & Active Site & $\mathrm{EC}_{50} \quad(\mathrm{mg} / \mathrm{mL})$ & $\mathrm{CC}_{50} \quad(\mathrm{mg} / \mathrm{mL})$ & SI & Ref. \\
\hline 1 & Silver-NPs & None & $0.44 \pm 0.91$ & $3.9 \pm 1.6$ & 8.86 & {$[1]$} \\
\hline 2 & Gold-NPs & Ethylene Glycol & 6.5 & $1.12 \pm 0.05$ & 0.17 & [2] \\
\hline 3 & $\begin{array}{c}\text { Graphene } \\
\text { quantum dots }\end{array}$ & None & $>0.0199$ & $0.0515 \pm 0.0089$ & $\leq 3$ & [3] \\
\hline 4 & $\begin{array}{c}\text { Graphene } \\
\text { quantum dots }\end{array}$ & CHI499 & $0.000066 \pm 0.000011$ & $0.0239 \pm 0.0096$ & 362.12 & [3] \\
\hline 5 & $\begin{array}{c}\text { Graphene } \\
\text { quantum dots }\end{array}$ & CDF119 & $>0.0132$ & $0.0558 \pm 0.0104$ & $\leq 4$ & [3] \\
\hline 6 & Carbon dots & $\begin{array}{c}\text { 4-carboxy-3- } \\
\text { chlorobenzeneboronic acid }\end{array}$ & 0.0267 & 1.9 & 71.16 & [4] \\
\hline 7 & Carbon dots & 2-aminophenyl boronic acid & 0.48 & 354.8 & 739.17 & Present study \\
\hline
\end{tabular}

\section{References}

[1] H. H. Lara, N. V. Ayala-Nuñez, L. Ixtepan-Turrent and C. Rodriguez-Padilla, Journal of Nanobiotechnology 2010, 8, 1-10.

[2] S. Vijayakumar and S. Ganesan, Current HIV research 2012, 10, 643-646.

[3] D. Iannazzo, A. Pistone, S. Ferro, L. De Luca, A. M. Monforte, R. Romeo, M. R. Buemi and C. Pannecouque, Bioconjugate Chemistry 2018, 29, 3084-3093.

[4] M. Z. Fahmi, W. Sukmayani, S. Q. Khairunisa, A. M. Witaningrum, D. W. Indriati, M. Q. Y. Matondang, J. Y. Chang, T. Kotaki and M. Kameoka, RSC Advances 2016, 6, 92996-93002. 